\title{
UPAYA MENINGKATKAN HASIL BELAJAR SISWA PADA MATA PELAJARAN MATEMATIKA DENGAN PEMBELAJARAN TATAP MUKA TERBATAS MELALUI METODE BLENDED LEARNING PADA MASA PANDEMI COVID-19
}

\author{
SITI ROFINGAH \\ Pascasarjana PMIPA, Universitas Indraprasta PGRI, Jakarta \\ e-mail: sitir.sr@gmail.com
}

\begin{abstract}
ABSTRAK
Prioritas utama penyelenggaraan pendidikan pada masa pandemi Covid-19 adalah untuk mengutamakan kesehatan dan keselamatan peserta didik, pendidik, tenaga kependidikan, keluarga, dan masyarakat secara umum, serta mempertimbangkan tumbuh kembang peserta didik dan kondisi psikososial. Kelangsungan belajar mengajar yang tidak dilakukan di sekolah berpotensi menimbulkan dampak negatif yang berkepanjangan. Mengantisipasi konsekuensi negatif dan isu dari pembelajaran jarak jauh, SMA Negeri 1 Kota Depok sesuai panduan pemerintah mengimplementasikan dua kebijakan baru Pembelajaran Tatap Muka Terbatas dan Kurikulum darurat (dalam kondisi khusus). Pada masa pandemi Covid-19 mengharuskan mengharuskan pembelajaran daring dan luring berjalan beriringan. Di sisi lain hasil belajar siswa yang diperoleh diharapkan tetap baik. Penulis melakukan Penelitian Tindakan Kelas sebagai upaya untuk meningkatkan hasil belajar pada masa pandemi Covid-19 dengan menggunakan pembelajaran Campuran (Blended Learning) yang mengkombinasikan metode pembelajaran tatap muka dengan pembelajaran jarak jauh. Berdasarkan hasil temuan pada siklus I dan siklus II ternyata pembelajaran Campuran (Blended Learning) dapat meningkatkan hasil belajar siswa pada mata pelajaran matematika Kelas XII IPA di SMAN 1 Kota Depok.
\end{abstract}

Kata Kunci: hasil belajar, pembelajaran masa pandemi Covid - 19, blended learning

ABSTRACT

The main priority of providing education during Covid-19 pandemic to prioritize health and safety of students, educators, education staff, families, and the community in general, as well as considering the growth of the students and their psycho social conditions. The continuity of teaching and learning process that is not carried out in the school has potential to have a long lasting negative impact. Anticipating the negative consequences and issues of distance learning, SMA Negeri 1 Kota Depok, according to government guidelines, has implemented two new policies for limited Face-to-face learning and an emergency curriculum ( under special conditions). During the Covid-19 pandemic, online and offline learning must be done side by side. On the other hand the student learning outcomes are expected have good final result. The writer conducted Classroom Action Research as an effort to improve students' learning outcomes during the Covid-19 pandemic by using Blended Learning method which combine Face-to face learning method with distance learning. Based on the cycle 1 and cycle 2, there were found that Blended learning can improve students' learning outcomes in Mathematics subject for 12 graders of Science subject at SMAN 1 Kota Depok.

Keywords: results of study, Learning of Covid-19 pandemic, blended learning

\section{PENDAHULUAN}

Prioritas utama penyelenggaraan pendidikan pada masa pandemi Covid-19 adalah untuk mengutamakan kesehatan dan keselamatan peserta didik, pendidik, tenaga kependidikan, keluarga, dan masyarakat secara umum, serta mempertimbangkan tumbuh kembang peserta didik dan kondisi psikososial. Beberapa kendala yang timbul dalam pelaksanaan Pembelajaran Jarak Jauh (PJJ) diantaranya kesulitan guru dalam mengelola PJJ dan masih terfokus dalam penuntasan kurikulum. Sementara itu, tidak semua orang tua mampu mendampingi anak-anak belajar di rumah dengan optimal karena harus bekerja ataupun kemampuan sebagai pendamping belajar anak. Para peserta didik juga mengalami kesulitan berkonsentrasi belajar 
dari rumah serta meningkatnya rasa jenuh yang berpotensi menimbulkan gangguan pada kesehatan jiwa. Kelangsungan belajar mengajar yang tidak dilakukan di sekolah berpotensi menimbulkan dampak negatif yang berkepanjangan. Dampak negatif tersebut diantaranya risiko putus sekolah dikarenakan anak "terpaksa" bekerja untuk membantu keuangan keluarga di tengah krisis pandemi Covid - 19. Banyak orang tua yang tidak bisa melihat peranan sekolah dalam proses belajar mengajar apabila proses pembelajaran tidak dilakukan secara tatap muka. Perbedaan akses dan kualitas selama pembelajaran jarak jauh dapat mengakibatkan kesenjangan capaian belajar, terutama untuk anak dari sosio-ekonomi berbeda. Tanpa sekolah, terdapat anak yang terjebak di kekerasan rumah tanpa terdeteksi oleh guru. Mengantisipasi konsekuensi negatif dan isu dari pembelajaran jarak jauh, SMAN 1 Kota Depok sesuai panduan pemerintah mengimplementasikan dua kebijakan baru Pembelajaran Tatap Muka Terbatas dan Kurikulum darurat (dalam kondisi khusus). Dalam pelaksanaannya tentunya tidak sedikit kendala yang dihadapi. Cuaca yang kurang baik kadang mempengaruhi jaringan internet, siswa yang kehabisan kuota serta adaptasi guru terhadap perkembangan teknologi digital membutuhkan waktu untuk membangun performa yang terbaik. Kendala - kendala ini menjadi catatan dan perbaikan pada siklus berikutnya. Beberapa hal dibenahi seperti memperkuat jaringan internet, bantuan kuota internet untuk siswa yang kurang mampu, membeli akun videoconference premium serta pendampingan oleh teknisi/ahli teknologi digital.

Berdasarkan panduan dari pemerintah pembelajaran tatap muka terbatas ini hanya boleh digelar secara terbatas dengan kapasitas 50\%. Keterbatasan ini mengharuskan sekolah untuk kreatif dan inovatif dalam menetapkan strategi pembelajaran yang efektif diantaranya adalah dengan pembelajaran blended learning). Pembelajaran Campuran (Blended Learning) adalah pembelajaran yang mencampurkan antara pembelajaran tatap muka dengan pembelajaran jarak jauh atau pembelajaran sinkron (Synchronous Learning ) dengan pembelajaran asinkron (Asynchronous Learning). Pembelajaran sinkron adalah pembelajaran yang menghadirkan murid dan guru pada waktu bersamaan sehingga memungkinkan interaksi langsung antara murid dengan guru, murid dengan murid atau murid dengan narasumber lain dipandu oleh guru. MEski sering diasosiasikan dengan luring, pembelajaran sinkron bisa dilakukan secara daring. PEmbelajaran asinkron adalah pembelajaran yang memungkinkan murid belajar tanpa butuh kehadiran guru pada waktu bersamaan sehingga murid bisa mengatur waktu, tempat, alur dan tempo belajarnya. Pembelajaran asinkron bisa dilakukan secara luring maupun secara daring. Pembelajaran asinkron bisa dilakukan dalam bentuk penguasaan materi secara mandiri, tugas kontekstual, proyek kolaborasi maupun refleksi personal. Pembelajaran sinkron bisa dilakukan melalui praktik, diskusi, refleksi bersama dan umpan balik. Pembelajaran sinkron dan asinkron saling melengkapi. Kelebihan pembelajaran sinkron adalah aktivitas belajar lebih interaktif, antusiasme belajar lebih tinggi dan umpan balik sesuai kebutuhan. Kelebihan pembelajaran asinkron adalah fleksibilitas jadwal, tempo tergantung murid dan umpan balik instan. Kelemahan pembelajaran sinkron adalah jadwal yang kaku, tempo tergantung guru, bergantung pada kehadiran dan kualitas guru. Kelemahan pembelajaran asinkron diantaranya adalah perasaan terisolasi, penurunan antusiasme dan bergantung pada kualitas bahan ajar.

Hasil belajar sangat penting dalam proses pembelajaran. Hasil belajar merupakan perubahan tingkah laku siswa secara nyata setelah dilakukan proses belajar mengajar yang sesuai dengan tujuan pembelajaran (Jihad, Asep dan Haris, Abdul, 2010: 15). Dalam pembelajaran matematika, hasil belajar dapat digunakan sebagai acuan tingkat pemahaman siswa dalam mengikuti pembelajaran matematika. Hasil belajar dapat pula digunakan sebagai acuan keberhasilan dalam pembelajaran.Salah satu faktor penentu hasil belajar siswa adalah metode-metode yang dilakukan oleh guru selama pelaksanaan proses pembelajaran. Masa pandemi Covid - 19 mengharuskan pembelajaran daring dan luring berjalan beriringan. Pembelajaran Campuran (Blended Learning) yang mengkombinasikan metode pembelajaran tatap muka dengan pembelajaran jarak jauh merupakan solusi yang tepat dan efektif. 


\section{METODE PENELITIAN}

Penelitian ini merupakan Penelitian Tindakan Kelas yang dilaksanakan di SMAN 1 Kota Depok dalam dua siklus. Instrumen yang digunakan dalam penelitian ini adalah tes hasil belajar bentuk uraian yang akan digunakan untuk mengukur hasil belajar siswa berupa soal uraian. Hasil tes akhir tersebut dianalisis statistik untuk nilai rata-rata kelas, daya serap, dan ketuntasan klasikalnya dengan nilai KKM 75. Sedangkan lembar observasi berisi indikatorindikator perilaku siswa seperti 1) antusias dalam mengikuti kegiatan pembelajaran, 2) interaksi antara siswa dengan guru, 3) interaksi antara siswa dengan siswa, 4) perasaan siswa selama proses pembelajaran, 5) aktivitas siswa dalam diskusi kelompok, dan 6) partisipasi siswa dalam menyimpulkan materi pelajaran.

\section{HASIL DAN PEMBAHASAN}

\section{Hasil}

Pembelajaran tatap muka terbatas membatasi kehadiran siswa di sekolah hanya 50\%, untuk menyatukan $50 \%$ siswa nya maka metode pembelajaran dengan blended learning menjadi solusi yang tepat. Metode ini memungkinkan pada saat pembelajaran berlangsung siswa yang terjadwal belajar dari rumah bisa mengikuti pembelajaran yang sedang berlangsung di sekolah dengan teleconference menggunakan media zoom meet, geogle meet atau media lain yang relevan. Penggunaan teknologi pendukung untuk memfasilitasi metode ini tentunya harus disiapkan dengan baik diantaranya jaringan internet yang stabil, papan tulis virtual, pen tab , web cam, akun video conference premium dan speaker aktif. Disamping itu didukung pula dengan learning management system (LMS) yang dikelola dengan baik sebagai fórum diskusi, melaksanakan quiz atau tes, share materi pelajaran, pengumpulan tugas dan lain - lain. Untuk pengembangan LMS ini SMAN 1 Kota Depok menggunakan aplikasi moodle.

Berdasarkan analisis hasil tes yang telah dilakukan oleh peneliti selama proses pembelajaran berlangsung dan pengisian angket yang diberikan kepada siswa, rnaka dapat diungkapkan mengenai hal-hal yang meliputi: hasil belajar siswa dan pemahaman materi melalui pelaksanaan refleksi pembelajaran.

Tabel 1 . Hasil Belajar Matematika pada Siklus I dan 2

\begin{tabular}{|c|c|c|c|c|c|c|}
\hline Siklus & $\begin{array}{c}\text { Jumlah } \\
\text { Siswa }\end{array}$ & Tuntas & $\begin{array}{c}\text { Nilai } \\
\text { Terendah }\end{array}$ & $\begin{array}{c}\text { Nilai } \\
\text { Tertinggi }\end{array}$ & $\begin{array}{c}\text { Nilai } \\
\text { Rata-rata }\end{array}$ & $\begin{array}{c}\text { Ketuntasan } \\
\text { belajar }\end{array}$ \\
\hline 1 & 37 & 31 & 50 & 100 & 86,9 & $83,8 \%$ \\
\hline 2 & 37 & 35 & 58,33 & 100 & 95,50 & $94,6 \%$ \\
\hline
\end{tabular}

Berdasarkan tabel hasil belajar Matematika pada Siklus I dari jumlah 37 siswa terdapat 6 siswa yang mendapat nilai kurang dari 75 atau ketuntasan belajar sebesar 83,8 \%, dan siswa yang mendapat nilai lebih dari sama dengan 75 adalah 31 siswa dengan nilai rata-rata kelas 86,9 dengan nilai terendah 50 dan nilai tertinggi 100.

Berdasarkan tabel hasil belajar Matematika pada Siklus II dari 37 siswa, terdapat 2 siswa yang mendapat nilai kurang dari 75 atau mencapai ketuntasan belajar sebesar 94,6 \%, dan siswa yang mendapat nilai lebih dari sama dengan 75 adalah 35 siswa dengan nilai rata-rata kelas 95,50 nilai terendah 58,33 dan nilai tertinggi 100 .

Tabel 2. Hasil analisis observasi kegiatan pembelajaran

\begin{tabular}{|c|c|c|}
\hline Kegiatan & $\begin{array}{c}\text { Observasi Kegiatan } \\
\text { Pembelajaran }\end{array}$ & Presentase \\
\hline Siklus I & $3,47$. & $82,4 \%$ \\
Siklus II & 4,00 & $90,3 \%$ \\
\hline
\end{tabular}




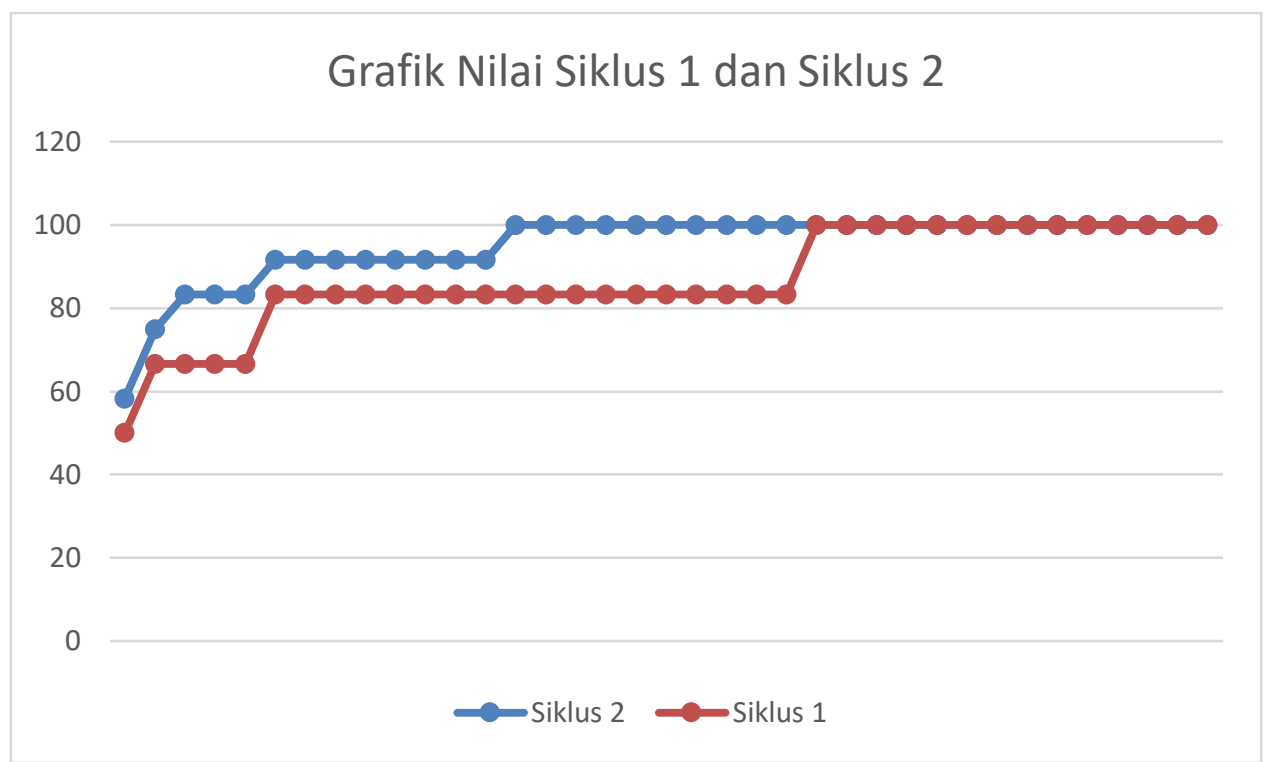

Gambar 1. Grafik Hasil Belajar Matematika pada Siklus I dan 2

Berdasarkan tabel tersebut menunjukkan bahwa siswa lebih mudah dalam menerima dan memahami materi pelajaran ketika metode blended learning diterapkan. Siswa lebih mengenal lebih dekat teman - teman sekelasnya dimana hal tersebut mampu memenuhi kebutuhan tumbuh kembang dan psikososial anak.

\section{Pembahasan}

Berdasarkan analisis hasil data penelitian, pada siklus I perolehan hasil di pembelajaran siklus I dari nilai rata-rata, ketuntasan klasikal, dan hasil observasi siswa dan guru maka siklus I perlu diulang kembali agar hasil belajar Matematika siswa kelas XII di SMAN 1 Kota Depok lebih meningkat dan ketuntasan belajar siswa dapat tercapai. Setelah melaksanakan pembelajaran siklus II maka nilai rata-rata dan hasil observasi siswa dan guru pada siklus II mengalami peningkatan dan ketuntasan klasikal belajar siswa telah sesuai dengan tujuan yang ingin dicapai maka penelitian hanya sampai pada siklus II sehingga tidak perlu mengulang pembelajaran sampai siklus berikutnya .

Berdasarkan hasil observasi dan refleksi pada siklus II dihasilkan temuan siswa mulai bisa beradaptasi dengan lingkungan belajarnya, mulai komunikatif dan aktif berdiskusi dalam proses pembelajaran, siswa juga merasa puas bisa berjumpa secara langsung dengan teman teman sekelasnya. Berdasarkan hasil belajar dan hasil observasi siswa dan obsevasi KBM guru pada akhir siklus II telah mengalami peningkatan dan telah sesuai dengan tujuan yang ingin dicapai maka penelitian hanya sampai pada siklus II.

Berdasarkan kajian dan pembahasan pada siklus I dan siklus II terdapat temuan-temuan sebagai berikut :

1. Proses pembelajaran berlangsung dengan lancar sehingga pembelajaran dapat berjalan sesuai dengan yang diharapkan. Hal ini terbukti dengan adanya peningkatan skor rata-rata hasil observasi kegiatan pembelajaran dari siklus I ke siklus II yang terlihat pada hasil penelitian.

2. Antusias, semangat dan keaktifan siswa meningkat dari siklus I ke siklus II.

3. Siswa mulai terampil beradaptasi dengan teknologi dan mulai lancar dalam prose kegiatan belajar mengajar dengan metode blended learning yang menyatukan pembelajaran dari sekolah maupun dari rumah.

4. Berdasarkan hasil nilai rata-rata siklus I dan siklus II dan hasil nilai rata-rata siklus II telah terjadi peningkatan nilai rata-rata dan peningkatan ketuntasan klasikal. yang terlihat pada tabel diatas. 
5. Siswa terlihat bahagia bisa bertatap muka langsung dengan guru dan teman - teman sekelasnya dalam pelaksanaan tatap muka walaupun terbatas pada $50 \%$ siswa.

6. Kecepatan siswa dalam memahami materi pelajaran matematika pada pembelajaran tatap muka terbatas lebih tinggi dari pembelajaran daring.

7. Pembelajaran tatap muka terbatas mengatasi rasa kejenuhan selama pembelajaran daring.

8. Metode blended learning menyatukan pembelajaran dari sekolah maupun dari rumah sehingga walaupun berbeda tempat tetap bisa saling bertegur sapa langsung serta tidak memisahkan siswa dalam 2 kelompok. Metode blended learning menjaga kebersamaan siswa dalam satu kelas.

Dari hasil analisis penelitian siklus I sampai dengan Siklus II maka dapat disimpulkan bahwa pemahaman siswa pada pokok materi matematika dengan metode pembelajaran blended learning telah mengalami peningkatan. Peningkatan ini dapat dilihat dari perolehan hasil belajar siswa berupa nilai rata-rata, daya serap dan ketuntasan klasikal. Berdasarkan hasil analisis data maka dapat disimpulkan bahwa model pengembangan blended learning layak digunakan dan sangat efektif untuk digunakan dalam proses pembelajaran. Hal tersebut disebabkan oleh beberapa faktor yaitu sebagai berikut.

Pertama, Model blended learning dapat meningkatkan kompetensi pengetahuan siswa. karena dapat membuat siswa belajar secara mandiri. Indikator dari kemandirian siswa adalah sikap bertanggung jawab terhadap tugas dalam pembelajaran. Hal ini didukung oleh (Ningsih, Misdalina, \& Marhamah, 2017; Sudjana, 2013) yang menyatakan bahwa mahasiswa mandiri dalam belajar memiliki tanggung jawab menonitor dirinya, keberhasilan siswa dalam belajar ditentukan oleh kemandirian belajar masing-masing. Pada masa pandemi Covid-19 seperti yang dirasakan sekarang ini, siswa diberikan hak penuh di dalam kelas dengan kontrol guru untuk mengakses segala informasi yang berhubungan dengan pembelajaran dengan menggunakan handphone atau laptop untuk memudahkan mencari informasi. Penelitian yang dilakukan oleh Risnani \& Husin (2019) yang menyatakan bahwa implementasi blended learning memberikan hasil belajar yang merata pada mahasiswa.

Kedua, Kedua, model blended learning dikembangan dengan mengikuti alur yang sistematis sehingga pembelajaran menjadi efektif dan efisian. Pembelajaran model blended learning dapat digunakan oleh siswa dimana dan kapan saja sehingga menjadi efektif dan efisien (Fitriana, 2017; Usman, 2018). Pembelajaran Tatap Muka Terbatas (PTMT) di SMAN 1 Depok dengan metode blended learning memadukan siswa yang belajar di sekolah dan belajar dari rumah megikuti pembelajaran secara bersama - sama dalam waktu yang sama, sistem ini memungkinkan siswa bisa mengikuti darimanapun siswa berada.

Ketiga, model blended learning yang dikembangkan dapat membuat suasana belajar menjadi nyaman dan menyenangkan. Suasana belajar yang nyaman dan menyenangkan akanberdampak pada meningkatnya motivasi siswa dalam belajar. (Arianti, 2017; Widodo, 2016) juga menyatakan bahwa suasana belajar yang menyenangkan akan meningkatkan kemampuan siswa dalam memahami dan menerima materi pembelajaran sehingga berpengaruh pada hasil belajar siswa. PTMT terbatas dengan blended learning memungkinkan siswa untuk bisa saling berkomunikasi langsung maupun tidak langsung, kondisi ini memungkinkan terpenuhinya kebutuhan psikososial anak.

\section{KESIMPULAN}

Penguasaan mata pelajaran matematika pada siswa kelas XII SMAN 1 Kota Depok dengan menerapkan metode blended learning meningkat signifikan terlihat dari hasil belajar dari Siklus I mengalami peningkatan ke siklus II. Pembelajaran tatap muka terbatas dengan blended learning memberikan kesempatan kepada siswa untuk bertatap secara langsung dengan teman sekelasnya walaupun terbatas sebanyak $50 \%$ dan sisanya $50 \%$ bertatap muka secara tidak langsung dengan teleconference memberikan rasa bahagia tersendiri bagi siswa, setidaknya hal ini mengurangi kejenuhan yang dirasakan selama pembelajaran daring. 


\section{DAFTAR PUSTAKA}

Arianti. (2017). Urgensi lingkungan belajar yang kondusif dalam mendorong siswa belajar aktif. Didaktika Jurnal Kependidikan, 11(1), 41-62. https://doi.org/ http://dx.doi.org/ 10.30863 /didaktika.v11i1.161

Asep Jihad dan Abdul Haris. (2010). Evaluasi Pembelajaran. Yogyakarta: Multi Press.

Fitriana, N. (2017). Penerapan Model Pembelajaran Blended Learning Pada Mata Kuliah Pemisahan Kimia Materi Kromatografi Untuk Meningkatkan Kualitas Belajar. Journal of Educational Inovation, 4(1), 46-54. https://doi.org/https://doi.org/

Hamzah B Uno. 2008. Model Pembelajaran Menciptakan Proses Belajar Mengajar yang Kreatif dan Efektif. Jakarta: Bumi Aksara

Heru Suparman, Mamik Suendarti, Deta Muliyani. (2019). Kurikulum Pendidikan Integrasi Dalam Pembelajaran. Tangerang: Pustaka Mandiri

Jared Stein and Charles R. Graham 2014, "Essential for Blended Learning: A Standards Based Guide".

Kementerian Pendidikan, Kebudayaan, Riset dan Teknologi. (2021). Materi Program Guru Belajar dan Berbagi Seri Semangat Guru Kemampuan Nonteknis dalam Adaptasi Teknologi. From : https://gurubelajardanberbagi.kemdikbud.go.id/

Muhammad Taufik Hidayat, Teuku Junaidi dan Muhammad Yakob. (2020). Pengembangan Model Pembelajaran Blended Learning dalam Meningkatkan Pemahaman Siswa Terhadap Tradisi Lisan Aceh. Jurnal Mimbar Ilmu, 25 (3), 401 - 410, from https://ejournal.undiksha.ac.id/index.php/MI/article/view/28913

Ningsih, \& Jayanti. (2016). Hasil Belajar Mahasiswa Melalui Penerapan Model Blended Learning Pada Mata Kuliah Persamaan Diferensial. Jurnal Pendidikan RAFA, 2(1), 111. Retrieved from http://jurnal.radenfatah.ac.id/index.php/jpmrafa/article/view/1237

Ningsih, Misdalina, \& Marhamah. (2017). Peningkatan Hasil Belajar dan Kemandirian Belajar Metode Statistika Melalui Pembelajaran Blended Learning. Al-Jabar: Jurnal Pendidikan Matematika, 8(2), 155-164. https://doi.org/https://doi.org/10.24042/ajpm.v8i2.1633

Peraturan Wali Kota Depok 2021 Nomor 66 Tahun Tentang Pedoman Penyelenggaraan Pembelajaran Tatap Muka Terbatas Di Masa Pandemi Corona Virus Disease 2019

Risnani, \& Husin. (2019). Section Articles Blended Learning: Pengembangan dan Implementasinya pada Mata Kuliah Fisiologi Tumbuhan. Bioeduscience, 3(2). https://doi.org/https://doi.org/10.29405/j.bes/3274-834007

Sudjana, N. (2013). Penilaian Hasil Proses Belajar Mengajar. Bandung: Remaja Rosdakarya

Suharsimi Arikunto, Suhardjono dan Supardi. (2006). Penelitian Tindakan Kelas. Jakarta: Bumi Aksara

Surat Keputusan Bersama Menteri Pendidikan dan Kebudayaan, Menteri Agama, Menteri Kesehatan, dan Menteri Dalam Negeri Republik Indonesia 2021 Nomor 03/KB/2021, Nomor 384, Nomor HK.01.08/MENKES/4242/2021 dan Nomor 440-717 Tentang Panduan penyelenggaraan Pembelajaran Di Masa Pandemi Corona Virus Disease 2019 (COVID-19).

Usman. (2018). Komunikasi Pendidikan Berbasis Blended Learning Dalam Membentuk Kemandirian belajar. Jurnal Jurnalisa, 4(1), 136-150. https://doi.org/https://doi.org /10.24252/jurnalisa.v4i1.5626

Widodo, W. (2016). Wujud Kenyamanan Belajar Siswa, Pembelajaran Menyenangkan, Dan Pembelajaran Bermakna Di Sekolah Dasar. Ar-Risalah, 18(2), 22-37. Retrieved from http://ejournal.iaiibrahimy.ac.id/index.php/arrisalah/article/view/123/137 